International Journal of Engineering \& Technology, $7(2.29)(2018) 251-256$
International Journal of Engineering \& Technology
SPC
Website: www.sciencepubco.com/index.php/IJET
Research paper

\title{
Service innovation capability, that spurs internationalization in Indonesian SMEs
}

\author{
Eka Sudarmaji ${ }^{1 *}$, Ismiriati Nasip ${ }^{2}$ \\ ${ }^{1}$ University of Pancasila \\ ${ }^{2}$ University of Bina Nusantara \\ *Corresponding author E-mail: esudarmaji@univpancasila.ac.id
}

\begin{abstract}
Many companies search and develop new innovations as pivotal activities for better approaches to fulfill the existing customer's requirements but failed to serve the future, service innovations that produce new markets. The absorptive capacity variables utilize the new external information and new knowledge in relation to the company innovativeness into the new product, new services, new processes, and new systems for internationalization achievement. This study investigates several factors that affect the service innovation capability based on samples of 38 Indonesian SMEs. We presume that our samples previously have a potential absorptive capacity as a basis to enhance their innovation capabilities and company's performance. We test the hypotheses on several samples of Indonesian SMEs, using multivariate OLS regression analysis and Multi Discriminant Analysis. The results indicate that the combined factors of "number sales \& marketing", "product launching" and the "customer involvement" have a significant effect on "internationalization" in as a representation of service innovation capability. By keeping these "science-push" and "demand-pull" of SMEs on innovation as a top priority, the innovation opportunity will be alive and better practice under AEC implementation.
\end{abstract}

Keywords: Indonesian SMEs; Internationalization; Service Innovation

\section{Introduction}

The previous research found that the internationalization of SMEs depends on two key internal components, i.e. R\&D capacity, and managerial structure and competency. Then it coupled with two external environments' variables, i.e. open innovation practices, government grants availability and technological development $(1,2)$.

This study discusses and explores absorptive capacity and service innovation impact to the internationalization of Indonesian SMEs. Many empirical studies explored the effect of innovation on firm' performance and the internationalization of SMEs. van de Vrande, de Jong, Vanhaverbeke, \& de Rochemont (2009) used 605 Dutch SMEs in the manufacturing and service divisions and found that there was open innovation implementation, and continuously trend towards the reception of open innovation among the companies (3). In Indonesia, implementation open innovation in the value chain could help Indonesian SMEs to sustain Indonesian (4).

The implementation of service innovation is one of the basic keys for successful organizations. Innovation in the manufacturing industry is different with innovation in the services industry. Innovation in the services industry mostly depends on curiosity made through intangible resources and processes, for example, knowledge, and learning. Hence, a new approach is required to assess and measure these intangible aspects of service innovation. Agarwal \& Selen developed a multidimensional structure to measure service, innovation and recognized the need to measure social capital that drives arranged coordinated effort as the key indicator of service innovation. Not only that, the external powers connected with the institutional, regulatory and rivalry measurements are the key variables to be incorporated into the estimation of service $(5,6)$. The biggest recipients of innovation tend to be the innovators, shareholders, and investors, and this creates a big gap between those subjects to capital versus labor.

\subsection{The Impact of Service Innovation in Business}

Many companies search and develop new innovations as pivotal activities for better approaches to fulfill the existing customer's requirements but failed to serve the future (7). Interruption happened due to innovative competitors through disruptive technologies that is normally cheaper, simpler and frequently and convenience to use. Thus, this new startup company can easily remove the settled incumbents. This disruption is frequently happening, as a new consumer' engagement and new patterns of consumer behaviors force company to adjust the way they design, develop, sales and channeling products and services.

The internet innovation development is easy to use by cell phone, it could gather people, resources, and information which subsequently make a better approach to consume goods and services at the same time. The other advantage is that they lower the boundaries for organizations and people to make income, changing the work environment for the individual and professional. The new technology such a social media platform (Facebook, Twitter \& Instagram) able to support Indonesian SMEs' business, rapidly rush into the new service (8). Indonesia will embrace Free Trade Agreement ("FTA") as well as technology's innovation, which cannot be avoided. The question that must be answered is whether FTA and technology's innovation provide 'benefits' for the Indo- 
nesia SMEs. A Similar question that must also be answered is whether the government regulations in the liberating market and investment will increase the innovation of SMEs and are they able to compete globally. Thus, FTA and technology's innovation are expecting to boost service innovation for Indonesian companies, especially for Indonesia SMEs. Technological innovations that make the distance and communication between companies and customers closer together. Technology that was originally worth hundreds of thousands of dollars and can now be enjoyed for free.

\section{The Literature Review}

\subsection{Absorptive Capacity as Antecedent for Service In- novation Capability}

Absorptive capacity represents the link the firm's internal capability and the absorption of a new external information availability couple with potential business opportunities, is described as the " ability of a company to identify, integrate it, and exploit it to the commercialization" (9). The theory applied for the ability for Indonesian SMEs to absorb new information can enable the company to have

innovation and affects the firm performance (10). It implies that the higher capacities, the more competitive the company is. The research areas of absorptive capacity are linked to open innovation theory. The company' dynamic capability underlined the company's abilities to reintroduce and exploit its company's capabilities for sustain (11) and having transient competitive advantages (12). Meanwhile, Henry (13) the creator and the father of open innovation said that the key components of "open innovation" are that essential creation originated from within and the outside of the company. Open innovation was identified as company's ability to use the internal and external information within organization to implement and adopt the innovation. These thoughts ought to be popularized by both using the present business plan and with alternative business models (13). By utilizing internal and external actors and data for value creation, the companies should look back at their organization's abilities since open innovation is asserted to be the new version of innovation.

The absorptive forces the company to absorb, utilize and transfer the new knowledge within the organization. The company's knowledge comes from four sources: 1) internal $R \& D$, 2) new knowledge from its own current operation, 3) external knowledge, and 4) buying new knowledge such as through purchase new equipment/software/machine or hiring new people or consultants The empirical researches on absorptive capacity found that only company who has high absorptive capacity is capable to absorb al external sources of knowledge. The capability to identify, to integrate and utilize the new knowledge is important for the company. Thus, this new knowledge should assert in the relationship with company's existing knowledge to gain the benefit from the new knowledge. There are two factors that induced the companies to absorb and exploit new knowledge: 1) the quantity of knowledge, and 2) the difficulty and costs incurred. Some new knowledge is even more expensive, but it tends to get cheaper in the future. Zahra \& George, (2002) founds that the external information need to acquire, integrate, transform and exploit within the organization environment will lead to the absorptive capacity capability in the company. The capacity of the subsidiary to absorb, assimilate and transfer knowledge is progressed as a premier territory of examination and as a valid dynamic capability.

The absorptive capacity identified the capability for company to develop new product development and supporting the relationship to external environment such as customers, suppliers, and even competitors (14). The absorptive capacity also creates the company to become more familiar with new technology and scientific innovation, Nieto \& Quevedo, (2005). Without a doubt, technological knowledge change the specialize abilities and also the skill influence for the company's product innovation (Domínguez et all., 2007; Tsai et al., 2012).
Open innovation is turning into a well-known issue in innovation management, and progressively taking a lead in a large corporation in terms of sustainable organization and profitability. There are two primary points of view i.e. the researcher who emphasize curiosity of open innovation and the movement of the close one, and the researchers who comment and inquire the oddity of open innovation by indicating past hypotheses and vagueness of the term of open innovation (15). There are many who supports or the ones who moved from close innovation into open innovation (16). Then again, there are contentions expressing that the open innovation idea can be followed even before they were marked as "open innovation" $(17,18)$. The researchers have been separated into two schools, the ones that are in "support" and the ones that are "against", thus Altman considered that the popularity of open innovation has prompted to numerous misinterpretations of any open business occasion or industry collaborative as open innovation, including a component of confusion about what open innovation is and its perceived novelty (15).

Open service innovation has been promoted as the vital business to maintain a strategic distance from the commoditization trap (19). The argument is to reconsider the business as a service business and to make intelligence of action plans that can take a better position of the commercialization of tangible goods. The accomplishment of the acknowledgment and dissemination of the concept of open service innovation does not appear to be on the grounds, yet a phenomenon in the ICT (information and communication technology) that had been happening for quite a while, yet caught and conceptualized in a way that it could be genuinely conveyed and meant for other content and segments rather than ICT itself (13). Commercialization can happen in different phases of the innovation process: nearer to the original invention (i.e. nearer to science and R\&D), among halfway phases of creating products and services, lastly nearer to the last client (i.e. the last commercialization).

This study is concerned with how Indonesian SMEs are reshaping its service innovation processes using the mobile technology or ICT. The concentration is the nature and outcomes of service innovation have been disclosed as they are connected from a service company perspective. In accordance to Grönroos (2001), nowadays, services is become the majority part of the company's activities and the customer's perspective apparently turns off the company's competitive avantages (21)

\subsection{Service Innovation Capability in Indonesian SMEs}

Since 2016 Indonesia has emerged with the ASEAN Economic Community ("AEC"), it implies that Indonesian's companies will compete other ASEAN companies in a single ASEAN market. Indonesia has nearly 40 percent of the region' economic, and it is critical that Indonesia should improve its capacity for innovation. Moving our conventional economy that now depends strongly on commodity items and low-wage works to one driven by innovation, will require change on numerous divisions. There are two territories where changes would have an especially capable effect on Indonesia's development limit, which is talent and smallmedium enterprises (22). In other words, modern economies have to be based on knowledge-based instead on capital and labor, which become the key factor of development (23).

Indonesian SMEs need to alert and tackle the boundary for moving from conventional economies to knowledge-based economies, and it is basic to perceive the individual and the organization. Individual abilities are principal for organization capacity. To survive and strengthen the company's needs to discover the best approach to innovating in such way, the knowledge is essential as fundamental and critical drivers in the present-day business environment. Knowledge and innovation are two sides of the coin; innovation is a utilization of knowledge and it transforms the knowledge into innovation. To manage the complexity, the Indonesian SMEs need to be ready to process knowledge from a wide range of fields and sources. 
In the term of SMEs, an external knowledge achievement and internal knowledge practices have embedded in their way of life. It is nature seeing that the practice of knowledge management in SMEs daily activities. These normal activities in SMEs can turn SME's capacities to renew and develop its capabilities (24). In this study, we attempt to explore and utilize the terms' absorptive capacity in Indonesian SMEs to implement the absorptive of knowledge capacities from external knowledge attainments as well as an internal knowledge practice.

The author understands that the subjective way of the absorptive capacity is an extremely difficult idea to measure quantitatively. Therefore, this study does not quantify the absorptive capacity but utilize the indicator i.e. R\&D, HR, suppliers affect, client effect, and so forth. Subsequently, we utilized the proxies of absorptive capacity that impacts innovation capability. This study likewise examines the Indonesian SMEs' absorptive capacities, its determinants and its significance for innovation.

The patterns of open innovation have been distinguished, it is expressed that open innovation had moved from large companies to SMEs (25). On the other hand, Keupp \& Gassmann (2009) also found that the uniqueness can speed up the SMEs' innovation process. Reasonable innovation can make the center capability for those SMEs. The usage of open innovation that has been fruitful in enterprises frequently accompanies arguments about the basic difficulties for the development of SMEs (26). SMEs can be arranged straightforwardly to the usage of open innovation because of their size and nature. The challenging rivalry and the customer's involvement have turned into an inspiration for SMEs.

Innovations inside SMEs in Indonesia are not those that occur inside large organizations, the innovation is not prepared and executed in their day by day exercises nor is it expressed in their business plan. Innovation has not been actualized into their schedules or refined inside their association and has just occurred through a few partners. The innovation established through people who feel that innovation will be valuable for their organizations. Hence an innovation in Indonesian SMEs is not everyday practices and attitude, and the innovative culture in their organization just happens to a couple of partners. The melting down in their organization starts through the person who believed that it would be valuable for the organization. Trial and error exercises in their product innovation most likely turned into management views, join with a tight measure of execution from every manager to operate the business unit.

The innovation performance can be measured from various perspectives, for instance, with the turnover of new things, supplements in productivity or declines in the progress cost of exhibiting new methodology, and customer reliability with new things. The measures of new innovation should be possible through 1) new or in a general sense improved things that are new to the company, and 2) new or basically upgraded things that are new to the market (innovation performance).

\section{Methodology/Materials}

This study uses a mix of literature reviews, qualitative and quantitative analysis, and the result will use multiple layers of data with a true objective to recognize significant progress. The primary data is the survey ("poll") and for this circumstance, the examination instruments were offered particularly to the business performers subjectively. The questionnaires are standard; the respondents are asked the same inquiries in comparable demand, and the results tend to be enduring. It's straightforward and strong. The relative examination used as the essential capacity to separate the data line by line to get the thoughts and associations between all elements.

This study surveyed the practices, particularly on "service innovation capability" of Indonesian SMEs, and investigated the presence of the variable "science push" and "demand pull" that have obtained by Indonesian SMEs. Models from Murovec \& Prodan (2009) and Zahra \& George (2002) are deployed into hypotheses. Perceiving the important information that fit for company, inte- grate within the organization then use it under this uncertainty environment will benefit for the company' future business (9). Therefore, the contribution from the government for empowering Indonesia SMEs is very important to avoid (27). Thus, research samples were taken only for the company that has utilized the grant from the government and has collaborated with state own enterprise (SOE) and universities.

This study will investigate the impact that can measure and predict service innovation capabilities of Indonesian SMEs. The usage of service innovation capability for SMEs will be the keyword distinction for this study. This study also depends on the hypotheses of theoretical while developing an essential model to investigate the factors that impact innovation capability strategies, which strengthen the business performance. The initial step is deciding the variables required in absorptive capacity theory in our framework view, and afterward, test the model of the relationship between variables in conjunction between two segments of absorptive capacity and service innovation capability. The variable required in this review comprised of several independent variables and one dependent variable. Both independent variables are the "science-push" and "demand-pull" that are accessible in the present environment and service innovation capability as a representation for internationalization. Hypothetical models represent the relationship between these variables as follows:

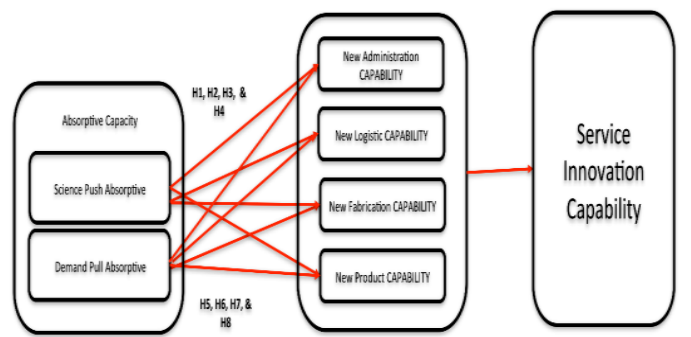

Fig. 1: Propose Research Model on Service Innovation Capability

H1 H8., In the presence of government grants \& information technology (internet) implementation, this study is going to analyze whether the "service innovation" as a representation of business growth performance is affected by "science-push" and "demand-pull". The hypothesis of service innovation capability is therefore evaluated by using empirical data that involves employees \& customers as the media to assess "service innovation" of Indonesian SMEs as the independent variable.

H1: Science push absorptive capacity has an influence on new administration capability;

H2: Science push absorptive capacity has an influence on new logistic capability;

H3: Science push absorptive capacity has an influence on new fabrication capability;

H4: Science push absorptive capacity has an influence on new product launching capability;

H5: Science push absorptive capacity has an influence on new administration capability;

H6: Science push absorptive capacity has an influence on new logistic capability;

H7: Science push absorptive capacity has an influence on new fabrication capability;

H8: Science push absorptive capacity has an influence on new product launching capability

An under Internationalization category, the twenty-four companies of the thirty-eight surveyed companies could be classified as "internationalization" companies, and the rest of them classified as "non-internationalization" companies. The classification of the twenty-four companies into the "internationalization" category was based on the fact that the surveyed companies actively participate in exporting activity at the time the survey was conducted. 


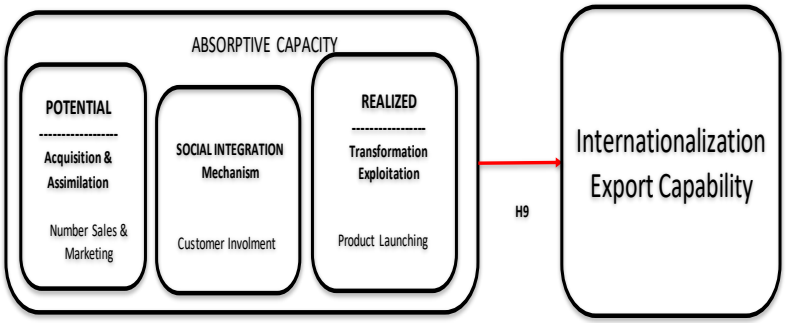

Fig. 2: Propose Research Model on Internationalization Export Capability

H9. To evaluate whether after controlling $\mathrm{H} 1 \sim \mathrm{H} 8$, there is any significant difference between the SMEs who are able to do "internationalization", as a means of survival, sustainable growth and has owned market over the other SMEs. Internationalization is going to differentiate both of them. Additionally, the organization performance of each SMEs will be grouping.

Basic data on this study is increased through the close and openended questionnaire. Research samples are Indonesian SMEs that are recorded in 'associations'. The samples collected according to the purposive sampling by criteria; 1) enlisted in the training program and promotion subsidy from government, whether it is from association, local government, or central government or government-related organizations, 2) incorporated into the criteria and attributes of SMEs, and 3) the SME has established and operated for at least two years before the review is taken. The samples were taken from three events, which are in Kunming, Nanning, and Bandung. Those Indonesian SMEs are in training agenda and market exhibition under the Association arrangement.

The total of seventeen questionnaires was distributed, but only twelve Indonesian SMEs who provided the response (respond rate 70.59\%) at 24th China Kunming Import and Export Fair 2016 in Kunming. Secondly, the total of twenty-nine questionnaires was distributed to furniture organizations, but only 12 Indonesian SMEs who provided the response (respond rate $41.38 \%$ ) at the 13th China Asean Expo (CAEXPO) 2016 in Nanning, Guangxi at 11-14 September 2016. Last surveys were given among the Indonesian SMEs under the direction of PT. "T" that was done in Bandung, Indonesia. The total of thirty-five surveys was distributed and only fourteen organizations provided the response (respond rate $40 \%$ ). The information in this study is comprised of quantitative data and under the assumption that all the absorptive capacity practices in Indonesian SMEs need to recognize and actualize it.

\section{Results and Findings}

The Figure 3. \& Table1 below shows that the innovative practices that Indonesian SMEs have done for almost the last three years. The highest goal for Indonesian SMEs for having innovation in the last three years were done for 'increasing customer satisfaction' $(21.95 \%)$ as same as highest for 'developing export market' $(21.95 \%)$ and 'developing a niche market for a special client' $(21.95 \%)$, followed by 'looking for market \& new client' $(20.12 \%)$ and 'develop export market' (14.02\%).

Table 1: Innovation Practices at Indonesian SMEs \begin{tabular}{|l|c|c|c|c|}
\hline Innovation for last 3 years by Company & Mean & STD & Frequency & \% Frequency \\
\hline
\end{tabular}

\begin{tabular}{|l|r|r|r|r|}
\hline Market \& New Clients & 1.736842 & 0.10455 & 66 & $20.12 \%$ \\
\hline Increase Customer Satisfaction & 1.894737 & 0.111816 & 72 & $21.95 \%$ \\
\hline Develop Export Market & 1.210526 & 0.146839 & 46 & $14.02 \%$ \\
\hline Develop Domestic Market & 1.894737 & 0.13488 & 72 & $21.95 \%$ \\
\hline Develop Niche Marjet for Special Clients & 1.894737 & 0.159076 & 72 & $21.95 \%$ \\
\hline
\end{tabular}

Value: $0=$ Null, $1=$ Low, $2=$ Medium $\&$ 3=High

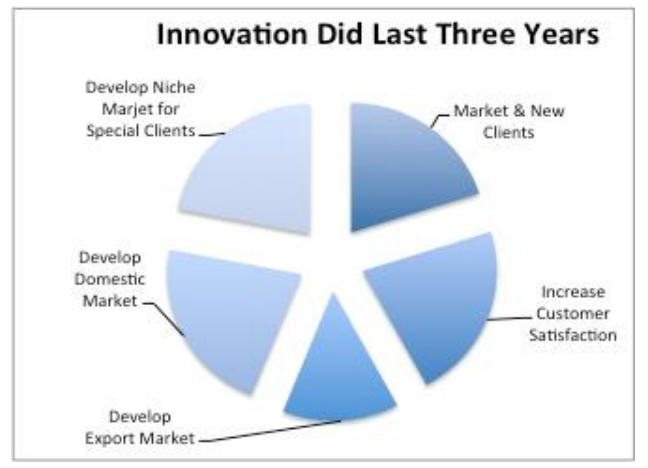

Fig. 3: Innovation Practices at Indonesian SMEs

This study found that the important sources of external knowledge that are able to assimilate into the internal firm knowledge can be shown in Figure. 4 \& Table2. It's shows that the most of the sources of external knowledge for Indonesian SMEs were taken from the attending and participating 'trade conference' $(28.40 \%)$, followed by 'iinternet' (26.54\%), 'government' $(24.07 \%)$ and the last is 'business association' $(20.99 \%)$.

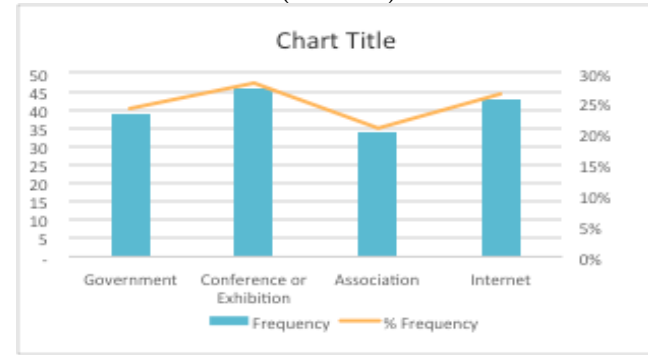

Fig 4: Source of Knowledge

Table.2: Source of Knowledge

\begin{tabular}{|c|l|c|c|c|r|c|}
\hline No & Government \& Tech & Mean & STD & Core of OI & Frequency & $\%$ Frequency \\
\hline 1 & Government & 1.0263 & 1.1965 & OTSIDE IN & 39 & $24.07 \%$ \\
\hline 2 & Conference or & 1.2105 & 1.2337 & OTSIDE IN & 46 & $28.40 \%$ \\
\hline 3 & Association & 0.8947 & 1.0853 & OTSIDE IN & 34 & $20.99 \%$ \\
\hline 4 & Internet & 1.1316 & 1.2980 & OTSIDE IN & 43 & $26.54 \%$ \\
\hline \multicolumn{7}{|r}{}
\end{tabular}

Value: $0=$ Null, $1=$ Low, $2=$ Medium \& $3=$ High

As per Table 3 below, the overall regression demonstrates the direction of the impact of every research object. The regression coefficient that has a positive sign signifies that eight variables from which "science-push" and "demand-pull" has positive effects on innovation ability. The correspondence has Adjusted R square and "Fvalue" value with "F 0.01 " or 0.01 significance level. The significance value less than "F $\mathrm{F}_{0.01}$ " or $1 \%$ demonstrates that these outcomes have the ability to show that those eight variables of "demand-pull", and "science-push " have the impact on "new service innovation".

Table 3: Univariate Regression Result with " $t$ " value and " $F$ " value

\begin{tabular}{|c|c|c|c|c|c|c|c|c|c|}
\hline & Absorptive Cap Determinant & Components & & Innovation Capability & Hypo & Significance F & "t" value $t_{01}$ & & Adj R Square \\
\hline & Copy from Com & Demand Pull & & New Administration & $\mathrm{H} 1$ & 1.83415E-11 & 9.598717972 & & 0.711242921 \\
\hline & STAFF MGT & Demand Pull & $\rightarrow$ & New Logistoc & $\begin{array}{ll}{ }_{2} 2 \\
\end{array}$ & 0.001535858 & 3.428502715 & 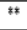 & 0.225206031 \\
\hline & BUY EQUIP & Demand Pull & $\rightarrow$ & New Fa & H4 & $3.52878 E-10$ & 8.5395682224 & . & 0.660314316 \\
\hline & Any & Demand Pull & $\rightarrow$ & Product Development & H5 & $2.21 E-06$ & 1.912874 & & 0.649897 \\
\hline & MARKET FEASIBLITYY & Science Push & $\rightarrow$ & New Administration & H7 & $1.20278 E \cdot 08$ & 7.334039899 & ***; & 0.587918856 \\
\hline & STAFF R\&D & Science Push & $\rightarrow$ & New Logistoc & H8 & 0.000447688 & 3.863841026 & ** & 0.273502215 \\
\hline & Advertising - & Science Push & & New Fabrication & H10 & $4.52037 \mathrm{E}-14$ & 11.93317948 & ** & 0.792601795 \\
\hline & Market Research & Science Push & $\rightarrow$ & Product Development & H11 & $3.30194 E-13 *$ & 11.12948915 & $* *$ & 0.768555484 \\
\hline
\end{tabular}

\section{* Not Siginicant at $0.01 \& 0.05$ (the lowest) \\ ** Siginicant at 0.01 \\ ${ }^{* * *}$ Siginicant at 0.05}

We found that the fourth of the components of "demand-pull" have significant sign effects on "copy from competitors", "number staff of management" and "purchasing new equipment" on "new administration", "new logistic" and "new fabrication" respectively. Unfortunately, there is no single component of "demand-pull" have significant on "product development". No significance value less than "F0.01" or $1 \%$ and/or "F0.05" or 0.05 demonstrate that these outcomes have no ability to show that those variable have the impact. The rest components of "science-push" have signifi- 
cant "market feasibility", "number staff of R\&D", "advertising trade fair \& conference" and "market research" on "New administration", "new logistic", "new fabrication" and "Product development" respectively.

This implies of seven variables of "science-push" and "demandpull" significantly affect service innovation capabilities for Indonesian SMEs. The two components of absorptive capacity "science-push" and "demand-pull" plays a vital part in affecting the operation. The two keys of the component were playing a pivotal role for the SMEs as an operator of change or important agent between the company and the markets. The greater part of them is giving the best guidance for the company to meet the clients' perceived value of the company's products or services. The vast majority of the information has completely absorbed by the organization. In view of the empirical findings, this study found that these outcomes are partially consistent with research directed by Murovec \& Prodan (2009).

International The results of these tests show that the data in this study fit for the next test of multiple regression analysis. The multiple linear regression equations as below:

\subsection{Internationalization Discriminant}

International The results of these tests show that the data in this study fit for the next test of multiple regression analysis. The multiple linear regression equations as below:

$\mathrm{Y}=\mathrm{a}+\mathrm{bX} 1+\mathrm{bX} 2+\mathrm{bX} 3+\mathrm{e}$

$\mathrm{Y}=0,6570+0,0080 \mathrm{X} 1+0,3718 \mathrm{X} 2-0,4117 \mathrm{X} 3+\mathrm{e}$ Whereas:

$\mathrm{a} \quad=$ Constant

b1-b3 $=$ The regression coefficient is the change of magnitude in the dependent variable due to changes in each unit of the independent variable.

$\mathrm{Y}=$ Internationalization

$\mathrm{X} 1=$ Number sales $\&$ marketing

$\mathrm{X} 2$ = Product launching

$\mathrm{X} 3$ = Customer involvement

$\mathrm{e} \quad=$ Residual error

The regression above shows the direction of the influence of each object of research. The regression coefficient that has a positive sign means "number of sales \& marketing", and "product launching" have a positive effect on "internationalization", while the regression coefficient has a negative sign means "customer involvement" have a negative effect on "internationalization". The equality has 'R-value' or correlation coefficient of 0.6236 ; Adjusted $R$ square of 0.5904 ; $F$ value of 18.7759 with 0.0001 significance level. The significance value less than 0.01 or $1 \%$ show that these results have the ability to show that "number of sales \& marketing", "product launching" and "customer involvement" have the effect on "internationalization".

On the individual variable view, the "number of sales \& marketing" has a significance level of 0.0284 with a " $t$ " value of 2.2892 it is less than 0.01 or $1 \%$. This means that "number of sales \& marketing" has a significant effect on internationalization for Indonesian SMEs. It indicated that "number of sales \& marketing" has a pivotal role in the operation. The "number manager and staff' in the sales \& marketing department is taking the big part for the SMEs as an important mode for the company with an external environment such as collaborators, 'competitors' and customers. Most of them were given the best advice for the company to meet the customers' perceived value of the company's products or the services. Most of the knowledge has fully absorbed by the company.

The level of significance of "customer involvement" has a negative sign, amounted to -5.3161 with a " $t$ " value of 0.000007 , it is less than 0.01 . This means that the "customer involvement" had a negative significant effect on "internationalization". It implies that "customer involvement" sign that the strong relationship between the SMEs and customer will not push the ability of the SMEs to get ultimate in service innovation. This happens as the customer plays an important role not to serve another customer besides them.
Logically since the production capacity has a limitation, the capacity to serve clients also limited. The limited capacity is the big obstacle in the SMEs operation.

The level of significance of "product launching" amounted to 3.0726 with a "t" value of 0.0042 , it is less than 0.01 . This means that the "product launching" had a significant effect on "internationalization". The "product launching" is a form transformation as the final output, plays an important role as proof as a precedent capacity. The "product launching" ability shown the SMEs ability to produce new products through new fabricates and the new administration.

The Z-score (0.6316) reveals that a significant predictive value of $81.58 \%$ for the SMEs who has "internationalization" while on the other hand has the predictive value that is even significantly higher with a percentage of $100.00 \%$ for those who have no "internationalization", which shows from Tabel.4 below. It shows that the three keys of "number of sales \& marketing", "product launching" and "customer involvement" have a very strong relationship with the 'internationalization' as a representation of business performances.

Table 4: Prediction Analysis

\begin{tabular}{|l|c|c|c|c|r|}
\hline Actual & Internationalization & $\%$ & Non Internationalization & $\%$ & Total Group \\
\hline Internationalization & 17 & $70.8 \%$ & 7 & $29.2 \%$ & 38 \\
\hline Non Internationalization & 0 & $0.0 \%$ & 14 & $100.0 \%$ & 14 \\
\hline
\end{tabular}

The results of the study can be summarized as follows: 1) "number sales \& marketing" has a significant effect on "internationalization" as a representation of service innovation capability. Testing results of significance level are smaller than the standard significance, 2) "product launching" has the positive significant effect on "internationalization" as a representation of service innovation capability, and 3) "customer involvement" has a negative significant effect on "internationalization" as a representation of service innovation capability. The results of testing the significance level are greater than the standard significance. Combine factors of "number sales \& marketing", "product launching" and the "customer involvement" have a significant effect on "internationalization" as a representation of service innovation capability. The results of testing the significance level are smaller than the standard significance.

This study investigated the key absorptive variables with additional one of new independent variable of "customer involvement" and "internationalization" as the dependent variable. Authors suggest that new additional variables need to explore for future research. On the other words, this study just tried two key inward sections i.e. the "science-push" and the "demand-pull" as independent variables, and "innovation capability" as the dependent variable.

\section{Conclusion}

This study merely assesses "sciences-push" and "demand-pull" of the absorptive capacity of Indonesian SMEs due to the rapidly developing environment. The 'knowledge-based framework' must be made by Indonesian SMEs using parts of "science-push" and "demand-pull" on a consistent basis due to the present and future business environment scene. By keeping these "science-push" and "demand-pull" of SMEs on innovation as a top priority, the innovation opportunity will be alive and better practice under AEC implementation. In another word, the Indonesia SMEs must upgrade their own particular innovation exercises, either as the new product, the new service, the new process or the new technology to fulfill their customers' demands. However, increasing the service innovation capabilities upon integration requires more resources, that in the scale of economic will probably not suit (the domestic market's demand).

In the future, many factors that cause the emergence of new ICT into the service innovation is the advancement of ICT improvement. Meanwhile, the AEC will push Indonesian SMEs to improve their performance, especially with the benefits of a single 
market of AEC: 1) AEC will increase business opportunities, 2) the competition for business will affect the Indonesian SMEs, 3) The tariffs and customs will diminish as well as minimum obstacles for trade.

\subsection{Research Limitation}

Another limitation is the context of the "demand-pull" and "science-push" of absorptive capacity keys components that are available during the period of study. The capability for Indonesian SMEs to utilize the absorptive capacity will depend on an ability to transfer the external-knowledge that match in the company's future goal (28). The utilization of ICT needs to be explored deeply as tools for transforming the tacit knowledge within Indonesian SMEs. Tacit plays a pivotal role in Indonesian SMEs, and ICT need to mediate this tacit knowledge as a vehicle to spread this knowledge among the stakeholders.

Orientation and motivations differ from Indonesian SMEs to the others, it could be because the stakeholders have different educational, cultural and social backgrounds. The author realizes that to quantify the qualitative of "absorptive capacity", "service innovation" and "ability to measure the internationalization" is a very difficult concept. Therefore, the author believes that there are many possible variables that cannot be traced on this study, especially the possibility of things that are common regarding the relationship between "internationalization", "demand push", "science push", "potential absorptive", "realized absorptive" and "service innovation capability" to "internationalization", and therefore, it cannot be counted or described statistically or quantitatively.

\subsection{Future Research}

Indonesian SMEs need to seek different approaches to business growth and progress, especially if they really want to survive. The knowledge-based organization is an important factor that makes Indonesia SMEs, to sustain and accelerate growth. The future study will still continue to explore a better framework for the absorptive capacity practices in Indonesian SMEs that is associated with a new round of free-trade developments. Future studies may incorporate with the knowledge based organization. Indonesia SMEs need to consider to tapping in into "knowledge-based organization, whereas knowledge drives overall companies' performance". Therefore, an appropriate framework is one of the most important requirements for encouraging Indonesian SMEs to participate in the ICT sector. Currently the Internet of things may the biggest factors and contributor to new product-service-system (PSS) based company as well as the knowledge-based.

\section{References}

[1] Sudarmaji E. Employing Open Innovation Where SMEs Need It Most: The Indonesian Perspective. In: 4th Gadjah Mada International Conference on Econimics And Business 2016. 2016. p. 696-709.

[2] Wynarczyk P. Open innovation in SMEs. J Small Bus Enterp Dev. 2013;20(2):258-78.
[3] van de Vrande V, de Jong JPJ, Vanhaverbeke W, de Rochemont M. Open innovation in SMEs: Trends, motives and management challenges. Technovation. 2009;29(6-7):423-37.

[4] Hamdani J, Wirawan C. Open Innovation Implementation to Sustain Indonesian SMEs. Procedia Econ Financ. 2012;4(Icsmed):223-33.

[5] Lee J dong, Park C. Research and development linkages in a national innovation system: Factors affecting success and failure in Korea. Technovation. 2006;26(9):1045-54.

[6] Lee S, Park G, Yoon B, Park J. Open innovation in SMEs-An intermediated network model. Res Policy. 2010;39(2):290-300.

[7] Christensen CM. The Innovator's Dilemma - When New Technologies Cause Great Firms to Fail. Harvard Business School Press. 2005.

[8] Sarosa S. Adoption of Social Media Networks by Indonesian SME: A Case Study. Procedia Econ Financ. 2012;4(0):244-54.

[9] Cohen W, Levinthal D. Absorptive Capacity: A New Perspective on Learning and Innovation Wesley M . Cohen; Daniel A . Levinthal Absorptive Capacity: A New Perspective on Learning and Innovation. Science (80- ). 1990;35(1):128-52.

[10]Rahab. Innovativeness Model Of Small And Medium Enterprises Based On Market Orientation and Learning Orientation: Testing Moderating Effect Of Business Operation Mode. Procedia Econ Financ. 2012;4(Icsmed):97-109.

[11]Eisenhardt KM, Martin JA. Dynamic capabilities: what are they? Strateg Manag J. 2000;21(10-11):1105-21.

[12] Mcgrath RG. Transient advantage- Rita McGrath. 2013;

[13]Chesbrough H. Open Innovation The New Imperative for Creating and Profiting from Technology. Vol. 53, Journal of Chemical Information and Modeling. 2003. 1689-1699 p.

[14] Murovec N, Prodan I. Absorptive capacity, its determinants, and influence on innovation output: Cross-cultural validation of the structural model. Technovation. 2009;29(12):859-72.

[15]Altmann P, Li J. The novelty of Open Innovation. Sch Bus Eng. 2011; Student Th(Jing Li):1-24.

[16]Enkel E, Gassmann O. Creative imitation: Exploring the Case of Cross-industry Innovation. R D Manag. 2010;40(3):256-70.

[17]Huizingh EKRE. Open innovation: State of the art and future perspectives. Technovation. 2011;31(1):2-9.

[18] O'Reilley DP. Open Innovation : Past Is Prologue. 2010;

[19]Chesbrough H. OPEN Services INNOVATION Rethinking Your Business to Grow and Compete in a New Era. Jossey Bass; 2011.

[20]Grönroos C. The Perceived Service Quality Concept - A Mistake? Manag Serv Qual. 2001;11(3):150-2.

[21] Kandampully J. Innovation as the core competency of a service organisation: the role of technology, knowledge and networks. Eur J Innov Manag. 2002;5(1):18-26.

[22]Burkner H-P. Taking Vietnam 's economy to the next level. World Econ Forum. 2015;1-4.

[23]Davenport TH, Prusak L. Working knowledge: how organizations manage what they know [Book Review]. IEEE Eng Manag Rev. 2005;31(4):301.

[24]Lichtenthaler U. Integrated Roadmaps for Open Innovation. Res Technol Manag. 2008;51(3):45-9.

[25] Gassmann O, Enkel E, Chesbrough H. The Future of Open Innovation. R D Manag. 2010;40(3):213-21.

[26] Lazzarotti V. Managing innovation networks of SMEs: a case study. ... Conf 2008 IEMC .... 2008;(Mi):1-5.

[27] Irjayanti M, Azis AM. Barrier Factors and Potential Solutions for Indonesian SMEs. Procedia Econ Financ. 2012;4(Icsmed):3-12.

[28] Susanty A, Handayani NU, Henrawan MY. Key Success Factors that Influence Knowledge Transfer Effectiveness: A Case Study of Garment Sentra at Kabupaten Sragen. Procedia Econ Financ. 2012;4(Icsmed):23-32. 